\title{
Correction to: Iron oxides nanoparticles (IOs) exposed to magnetic field promote expression of osteogenic markers in osteoblasts through integrin alpha-3 (INTa-3) activation, inhibits osteoclasts activity and exerts anti-inflammatory action
}

\author{
K. Marycz ${ }^{1,2,4^{*}}$, P. Sobierajska ${ }^{3}$, M. Roecken², K. Kornicka-Garbowska ${ }^{1,4}$, M. Kępska ${ }^{1}$, R. Idczak ${ }^{3}$, J.-M. Nedelec ${ }^{5}$ \\ and R. J. Wiglusz $z^{3,6}$
}

\section{Correction to: J Nanobiotechnol (2020) 18:33} https://doi.org/10.1186/s12951-020-00590-w Following publication of the original article [1], the authors identified an omission in the 'Funding' section. The updated 'Funding' section is given below and the added statement has been highlighted in bold typeface.

Research was founded by National Science Centre Poland grant no: 2017/26/M/NZ5/01184. The research is co-financed under the Leading Research Groups support project from the subsidy increased for the period 2020-2025 in the amount of $2 \%$ of the subsidy referred to Art. 387 (3) of the Law of 20 July 2018 on Higher Education and Science, obtained in 2019.

\section{Author details}

${ }^{1}$ The Department of Experimental Biology, University of Environmental and Life Sciences Wroclaw, Norwida 27B, 50-375 Wrocław, Poland. ${ }^{2}$ Faculty of Veterinary Medicine, Equine Clinic-Equine Surgery, Justus-LiebigUniversity, Frankfurter 108, 35392 Giessen, Lahn, Germany. ${ }^{3}$ Institute of Low
Temperature and Structure Research, Polish Academy of Sciences, Okolna 2, 50-422 Wrocław, Poland. ${ }^{4}$ International Institute of Translational Medicine, Jesionowa 11, Malin, 55-114 Wisznia Mała, Poland. ${ }^{5}$ Université Clermont Auvergne, CNRS, SIGMA Clermont, ICCF, Clermont-Ferrand, France. ${ }^{6}$ Centre for Advanced Materials and Smart Structures, Polish Academy of Sciences, Okolna 2, 50-950 Wrocław, Poland.

Published online: 19 May 2020

\section{Reference}

1. Marycz K, Sobierajska P, Roecken M, Kornicka-Garbowska K, Kępska M, Idczak R, Nedelec JM, Wiglusz RJ. Iron oxides nanoparticles (IOS) exposed to magnetic field promote expression of osteogenic markers in osteoblasts through integrin alpha-3 (INTa-3) activation, inhibits osteoclasts activity and exerts anti-inflammatory action. J Nanobiotechnol. 2020;18(1):33. https://doi.org/10.1186/s12951-020-00590-w.

\section{Publisher's Note}

Springer Nature remains neutral with regard to jurisdictional claims in published maps and institutional affiliations. adaptation, distribution and reproduction in any medium or format, as long as you give appropriate credit to the original author(s) and the source, provide a link to the Creative Commons licence, and indicate if changes were made. The images or other third party material in this article are included in the article's Creative Commons licence, unless indicated otherwise in a credit line to the material. If material is not included in the article's Creative Commons licence and your intended use is not permitted by statutory regulation or exceeds the permitted use, you will need to obtain permission directly from the copyright holder. To view a copy of this licence, visit http://creativeco mmons.org/licenses/by/4.0/. The Creative Commons Public Domain Dedication waiver (http://creativecommons.org/publicdomain/ zero/1.0/) applies to the data made available in this article, unless otherwise stated in a credit line to the data. 